\title{
HORMONE THERAPY REDUCES BONE RESORPTION BUT NOT BONE FORMATION IN POSTMENOPAUSAL ATHLETES
}

\author{
Suzy Y Honisett ${ }^{1}$, David Pagliaro ${ }^{1}$, Kathy Tangalakis ${ }^{1}$, Bronwyn Kingwell ${ }^{2}$, Peter Ebeling ${ }^{3}$, \\ Robyn Craven ${ }^{4}$, Juliana Antonopillai ${ }^{1}$, Vasso Apostolopoulos ${ }^{1}$, Lily Stojanovska ${ }^{1, *}$ \\ ${ }^{1}$ Centre for Chronic Disease, College of Health and Biomedicine, Victoria University, Melbourne VIC \\ Australia \\ ${ }^{2}$ Baker Heart Research Institute, Prahran, VIC Australia \\ ${ }^{3}$ Department of Diabetes, Endocrinology and Medicine, The University of Melbourne, The Royal \\ Melbourne Hospital, Parkville, VIC Australia \\ ${ }^{4}$ Women's Health and Breast Clinic, Freemasons Hospital, East Melbourne, VIC Australia
}

Corresponding Author: Lily Stojanovska, Centre for Chronic Disease, College of Health and Biomedicine, St Albans Campus, Victoria University, VIC 3021, Australia; tel: +613 99192737; fax: tel: +613 99194565;

e-mail: lily.stojanovska@vu.edu.au

\begin{abstract}
Introduction: Independently, hormone therapy and exercise have well-established protective effects on bone parameters. The combined effects of hormone therapy and exercise, however, are less clear. We, therefore, examined the effects of hormone therapy on bone turnover markers in postmenopausal women undergoing regular high intensity exercise.

Methods: In a randomised, double blind study, postmenopausal athletes competing at Masters level, received either hormone therapy $(50 \mu \mathrm{g}$ transdermal oestradiol, $5 \mathrm{mg}$ MPA, $\mathrm{n}=8)$ or placebo $(\mathrm{n}=$ 7) for 20 weeks. Women were tested before and after treatment for plasma concentrations of oestradiol, FSH, LH, and serum bone formation marker -osteocalcin (OC); and urine bone resorption markers-pyridinoline (PYD) and deoxypyridinoline (DPD).

Results: As a result of treatment with hormone therapy there were significant reductions in levels of FSH $(73.3 \pm 13.7$ to $48.6 \pm 10.5 \mathrm{mmol} / \mathrm{L}, p=0.01)$ and bone resorption markers (PYD, $81.9 \pm 7.7$ to $57.8 \pm 3.7 \mathrm{nmol} / \mathrm{mmol} \mathrm{Cr}, p=0.001$, and DPD, $18.5 \pm 3.1$ to $11.8 \pm 2.1 \mathrm{nmol} / \mathrm{mmol} \mathrm{Cr}, p=0.01)$. Oestradiol and bone formation markers were not significantly altered as a result of hormone therapy. There were no changes to any variables with placebo treatment.

Conclusion: Hormone therapy reduced bone resorption, but not bone formation, in postmenopausal athletes. These favorable reductions in bone turnover; therefore, provide an effective treatment in combination with high intensity exercise to further reduce the subsequent risk of osteoporosis and associated fractures.
\end{abstract}

Keywords: Exercise, menopause, bone turnover, hormone replacement therapy, estradiol

\section{Introduction}

Menopause is associated with an increase in bone turnover markers [1-3], and an elevated risk of osteoporotic fractures [1, 3, 4]. Hormone therapy and exercise are 2 interventions commonly prescribed to ameliorate this risk.

Estrogen administration has been shown to slow bone loss in postmenopausal women
[5-7], providing protection against the development of osteoporosis and the risk of fracture [8]. This reduction in bone loss is apparent in measures of biochemical markers of bone formation and resorption, with estrogen producing a net reduction in these markers $[9,10]$.

A number of meta-analysis studies have been conducted that assess the effects of phy- 
sical activity on bone loss in pre- and post- menopausal women. High impact exercise increases bone mineral density (BMD) in premenopausal women $[11,12]$, whereas, 8 months of Astanga yoga program provide beneficial effect on bone formation but did not improve BMD in premenopausal women. One study [13] found that the overall treatment effect of endurance training regimes prevented or reversed almost $1 \%$ of bone loss per year in lumbar spine and femoral neck, whilst two other meta analyses $[14,15]$ found a beneficial effect of impact exercise on the spine in post-menopausal women.

Despite these positive independent associations of exercise and hormone therapy on bone parameters, there are only limited number of studies that have examined their combined effects in a postmenopausal population. The potential benefits of physical activity in synergy with hormone therapy are inconsistent, and the results unclear [16, 17]. Prospective studies have reported improved bone mineral density (BMD) after initiating hormone therapy and exercise in previously sedentary postmenopausal women $[16,17]$. However, it is difficult to ascertain in these studies what proportions of the beneficial effects are attributable to initiating exercise or hormone therapy. Although this area is not new, it illustrates the need for a well-controlled approach to this topic, which addresses a direct comparison of exercise with hormone therapy, whereby both interventions are carried out optimally.

Herein, we determined whether hormone therapy would provide further improvement to bone turnover when given to postmenopausal women currently undertaking regular high intensity weight bearing exercise.

\section{Methods}

\section{Subjects}

Postmenopausal women were recruited from 'Masters' athletic running associations. Sixteen women were measured at baseline and fifteen women completed the study. The criteria for inclusion were: $1-5$ years postmenopause; aged between 45-60 years; competing at 'Masters' level in athletics, or vigorously running, jogging or cycling at least 4 times a week; a $\mathrm{VO}_{2}$ max of greater than $30 \mathrm{ml} / \mathrm{min} / \mathrm{kg}^{2}$ which isconsidered very good to high cardio-respiratory fitness for age. The criteria for exclusion were: taking any form of hormone therapy; previous hysterectomy or oophorectomy; family history of malignancies; established cardiovascular disease; smoking; excessive alcohol use or taking any drug therapy that would affect bone mineral and mineral metabolism. All women were cleared for participation following a full physical examination by a clinician. Recruited women were randomly assigned into two groups using a double blind design. Eight women were assigned into the 'ill group', and commenced using transdermal oestradiol patches (Estraderm $50 \mu \mathrm{g}$ twice/week, Novartis Pharmaceuticals, North Ryde, NSW, Australia) and oral medroxyprogesterone acetate (MPA, $5 \mathrm{mg} /$ day, Pharmacia Pharmaceuticals, Rydalmere, NSW, Australia). Seven women were assigned to the 'placebo' group and commenced using placebo patches and oral placebo tablets. One woman dropped out of the study due to skin irritation caused by the trans-dermal patch. All women gave informed consent to participate in this study, which was approved by the Human Ethics Committee, Victoria University (991017/CO484).

\section{Protocol}

All women underwent a number of measures at baseline ( $\mathrm{Tl}$ ) and at twenty weeks (T2). These included: blood samples for measurement of oestradiol, luteinising hormone (LH), follicle stimulating hormone (FSH), and the bone formation marker osteocalcin (OC), urine samples two hours post-first morning void for measurement of the bone resorption markers pyridinoline (PYD) and deoxypyridinoline (DPD); and aerobic capacity. Height, weight and body mass index (BMI) were also determined for all subjects. The above-mentioned biochemical markers of bone formation and resorption are of value in estimating bone turnover and have been used to reliably and consistently identify rapid bone losses [18]. Cross-sectional studies [3, 19] have shown that bone turnover rates, evaluated by these markers, increase at menopause and remain elevated, whilst bone turnover rates in postmenopausal women correlate negatively with BMD [20]. Participating subjects were requested to maintain their current training routine and diet throughout the study. 


\section{Assays}

Serum oestradiol was measured using a competitive chemiluminescent immunoassay (Gba-Coming, Medfield, MA, USA). FSH and LH were measured using a two-site chemiluminescent (sandwich) immunoassay (Gba-Coming, Medfield, MA, USA). Serum OC was measured by radioimmunoassay using the osteocalcin RIA kit (Incstar Corp., Stillwater, MN, USA). Total PYD and DPD cross -links of type I collagen were measured in hydrolyzed urine samples by high performance liquid chromatography, corrected for urine creatinine and expressed as nmol/ mmol Cr [1].

\section{Aerobic Capacity $\left(\mathrm{VO}_{2} \max \right)$}

The laboratory where the trials were conducted was maintained at a constant temperature $\left(20 \pm 1{ }^{\circ} \mathrm{Q}\right.$ and humidity $(44 \pm 2 \%)$. A 12 lead ECG (Montara, X-scribe, Stress testing System, Milwaukee, USA) was used to monitor subjects' heart rhythm and rate throughout the duration of the test. Subjects exercised on a stationary bicycle ergometer (Cybex Metabolic System, Met 100, Huntsville, USA) at a constant cadence of $70 \mathrm{rpm}$. Increments in cycle resistance occurred, commencing at 35 watts and increasing by 10 watts every minute. These increments continued until the subject felt they could not continue due to exhaustion, or until the subject experienced discomfort, or the practitioner stopped the test for medical reasons. Each subjects' oral gas expiration was measu- red via Vacumetric Vista Turbofit Software package (Version 3.2, Ametek, Pittsbergh, USA) to determine their respiratory exchange ratio (RER) and $\mathrm{VO}_{2}$ max. Both variables were subsequently charted throughout the duration of the exercise to ensure that their aerobic threshold was reached. Subjects were expected to have reached their $\mathrm{VO}_{2}$ max (a measure of maximal aerobic capacity) when at least two of the following criteria were achieved (a) a plateau of $\mathrm{VO}_{2}$ max readings, (b) exercising heart rate to within 10 beats of subjects' maximal heart rate, (c) an RER of greater than 1.10.

\section{Statistical Analysis}

The data were analysed using Sigma Stat. 2.0 Gandell, USA). The data are reported at baseline as mean \pm standard error of the mean (SEM). Changes to variables with treatment are reported as percent change from baseline. A Student's paired t-test was used to determine significance of changes with treatment. At-test was used to determine differences between treatment groups at baseline. Significance was reported as $p<0.05$.

\section{Results}

There were no significant differences between the two groups at baseline for: age, BMI, $\mathrm{VO}_{2}$ max, serum oestradiol and gonadotrophin levels, OC and DPD (Table 1). Urine PYD was significantly higher in the HRT group compared at baseline with the placebo group $(p=0.03)$ (Table 1).

Table 1

Baseline groups characteristics in the two groups of postmenopausal athletes

\begin{tabular}{|l|c|c|}
\hline Variable & $\begin{array}{c}\text { Placebo } \\
\mathbf{N}=\mathbf{7}\end{array}$ & $\begin{array}{c}\text { Hormone } \\
\text { Therapy } \\
\mathbf{N}=\mathbf{8}\end{array}$ \\
\hline Age, years & $54.7 \pm 1.3$ & $53.8 \pm 1.8$ \\
\hline BMI, kg.m ${ }^{2}$ & $22.2 \pm 1.2$ & $23.5 \pm 1.2$ \\
\hline Estradiol, $\mathrm{mmol} / \mathrm{L}$ & $76.1 \pm 12.1$ & $55.1 \pm 26.1$ \\
\hline $\mathrm{FSH}, \mathrm{mmol} / \mathrm{L}$ & $70.8 \pm 13.5$ & $73.3 \pm 13.7$ \\
\hline $\mathrm{LH}, \mathrm{mmol} / \mathrm{L}$ & $38.2 \pm 6.7$ & $40.9 \pm 9.1$ \\
\hline $\mathrm{VO}_{2} \mathrm{max}, \mathrm{ml} / \mathrm{kg} / \mathrm{min}$ & $35.6 \pm 3.0$ & $35.2 \pm 2.0$ \\
\hline Osteocalcin, $\mathrm{U} / \mathrm{L}$ & $32.5 \pm 9.9$ & $31.2 \pm 10.2$ \\
\hline $\mathrm{PYD}, \mathrm{nmol} / \mathrm{mmol} \mathrm{Cr}$ & $64.0 \pm 7.0$ & $81.9 \pm 7.3 *$ \\
\hline $\mathrm{DPD}, \mathrm{nmol} / \mathrm{mmol} \mathrm{Cr}$ & $13.4 \pm 1.8$ & $18.5 \pm 3.1$ \\
\hline
\end{tabular}

Values are mean \pm SEM. BMI indicates body mass index; FSH, follicle stimulating hormone; LH, luteinising hormone; $\mathrm{VO}_{2}$ max, maximal aerobic capacity; PYD, pyridinoline; DPD, deoxypyridinoline. * indicates a significant difference, $p<0.05$, between groups 
After 20 weeks of treatment, there were no significant changes in any parameter in the placebo group. However, in the HRT group FSH levels significantly decreased $(73.3 \pm 13.7$ to 48.6 $\pm 10.5 \mathrm{mmol} / \mathrm{L}, p=0.01$, mean $\pm \mathrm{SEM}$ ) indicating that subjects were compliant with HRT. Medication compliance was verified by medication counts.

$\mathrm{VO}_{2}$ max was unchanged in both groups (HRT group $35.2 \pm 2.0$ to $37.0 \pm 2.1 \mathrm{ml} / \mathrm{kg} / \mathrm{min}$, $p=0.27$; placebo group $35.6 \pm 3.0$ to $34.6 \pm$ $3.6 \mathrm{ml} / \mathrm{kg} / \mathrm{min}, p=0.66$ ) indicating that sub- jects maintained their existing exercise training regimen and fitness level throughout the duration of the trial. The bone formation marker, OC, remained unchanged with HRT administration $(31.26 \pm 10.2$ to $32.3 \pm 11.8, p=0.53)$. However, there were significant reductions in both bone resorption markers after 20 weeks of HRT, with PYD decreasing by $27.3 \%(81.9 \pm$ 7.3 to $57.8 \pm 3.7, p=0.001)$ and DPD decreasing by $33.0 \%(18.5 \pm 3.1$ to $11.8 \pm 2.1, p=$ 0.01 ) from baseline (Figure 1).

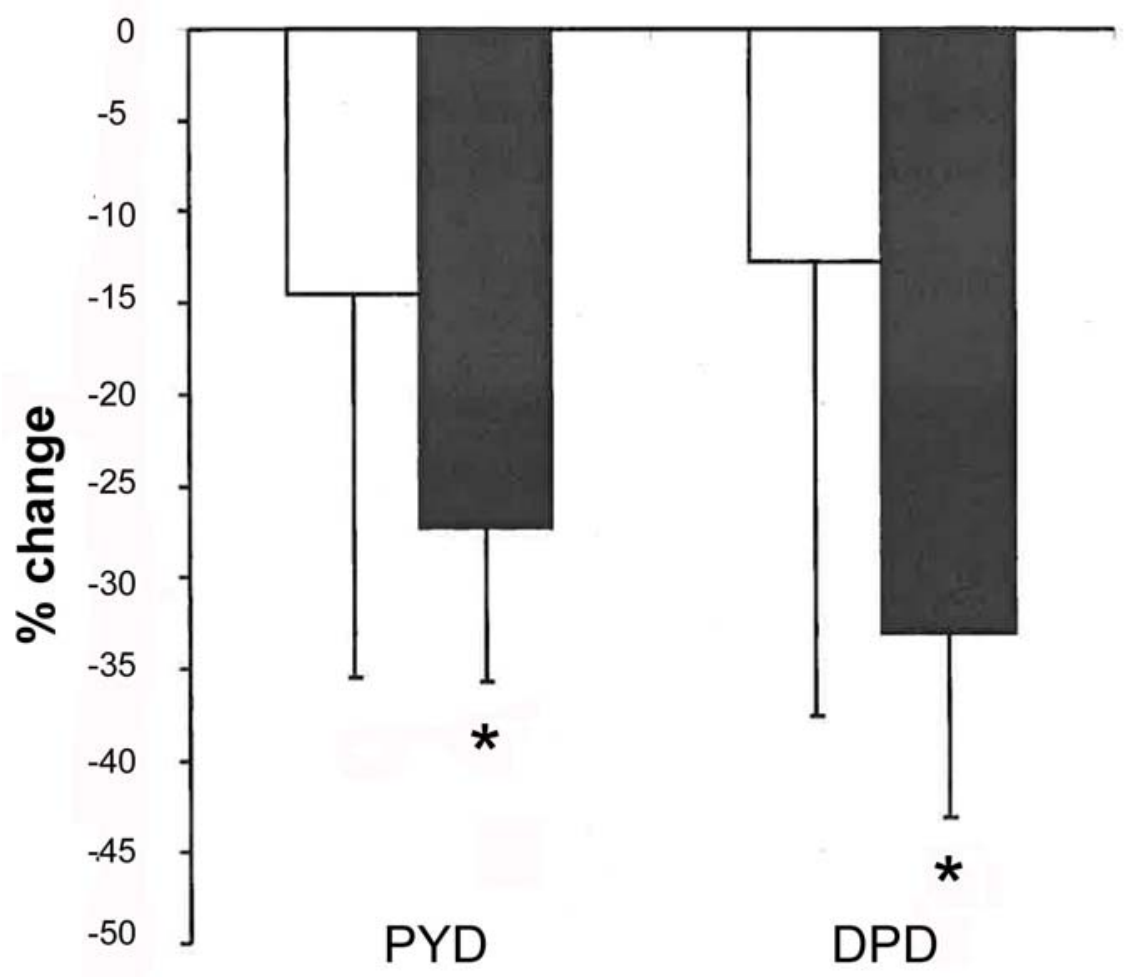

Figure 1 - Percentage change from baseline in resorption markers with placebo (white) and hormone replacement therapy (HRT) (black) treatment in postmenopausal athletes

\section{Discussion}

The results of this study demonstrate that athletically trained postmenopausal women are able to significantly reduce bone resorption with the use of hormone therapy; indicating that a combined intervention exceeds the effects of exercise alone on bone.

Many older women are involved in endurance-based exercises such as running, jogging and cycling, and compete at 'Masters' level athletics. For these women skeletal integrity is an important issue that may affect their continued performance in their chosen event after menopause. An improvement in BMD is shown with endurance exercise [13]; however, this form of exercise is not as effective as resistance or weight training [21]. Animal studies have shown that maximal osteogenesis occurs with highmagnitude strains applied with few strain cycles, as performed with resistance training [2225]. Moreover, in a postmenopausal osteoporosis rat model, exercise significantly increased bone mass by both inhibiting bone resorption and increasing bone formation in trabecular bones [26]. Therefore, to assist in the maintenance and/or improvement of skeletal integrity after menopause, hormone therapy is a viable option. 
There have been a number of prospective studies assessing the effect of combined treatment on BMD in postmenopausal women yielded conflicting results $[16,17]$. One study identified that weight bearing exercise and hormone therapy independently increased BMD at sites of lumbar spine and proximal femur, while a combined treatment provided an additive effect on BMD at lumbar spine and was synergistic for total body BMD [16]. Another study has shown that combined resistance training and hormone therapy increased BMD at sites of radial mid-shaft, spine and total body, while hormone therapy alone was associated with no change, or bone maintenance, after one year [17]. The effect of exercise alone was not measured in this study making it difficult to assess whether BMD accretion was due to the combination of treatments or due to the effect of exercise alone. In contrast to these studies, another prospective study found moderate exercise alone, including weight lifting, provided no changes in BMD, whilst the combination of exercise and hormone therapy provided no greater benefit in comparison to hormone therapy alone [27]. All of these studies introduced exercise in previously sedentary women, making it difficult to determine whether any changes in bone status were due to the initiation of exercise or the commencement of hormone therapy. None of the studies addressed endurance based exercise regimes. One recent cross-sectional study investigating 'Masters' trained postmenopausal athletes found that the women replacing estrogen had greater BMD of the hip, spine and total body compared with athletes not replacing estrogen [28]. However, years post-menopause were significantly greater in the women not replacing estrogen, possibly affecting BMD values and limiting the conclusions from this study.

The present study investigated women currently involved in endurance-based weight bearing exercises and provided a direct comparison of interventions using a well-controlled approach. This study assessed the impact of hormonal therapy treatment for 20 weeks on bone turnover markers that, to the best of our knowledge, have not been addressed in this population of postmenopausal athletes before.

Interestingly in this population of postmenopausal athletes, hormone therapy for 20 weeks provided added benefit to bone status by significantly decreasing bone resorption but not bone formation, suggesting that these interventions may be highly effective when used in combination to further reduce the risk of bone loss and osteoporotic fracture. Larger controlled prospective studies of longer duration are required to assess effects of hormonal therapy and endurance-based weight bearing exercise on bone density.

\section{REFERENCES}

1. Ebeling PR, Atley LM, Guthrie JR, Burger HG, Dennerstein L, Hopper JL, et al. Bone turnover markers and bone density across the menopausal transition. J Clin Endocrinol Metab. 1996; 81: 3366-71.

2. Slemenda C, Hui SL, Longcope C, Johnston CC. Sex steroids and bone mass. A study of changes about the time of menopause. J Clin Invest. 1987; 80: 1261-9.

3. Garnero P, Sornay-Rendu E, Chapuy MC, Delmas PD. Increased bone turnover in late postmenopausal women is a major determinant of osteoporosis. J Bone Miner Res. 1996; 11: 337-49.

4. Rosen CJ, Chesnut CH, 3rd, Mallinak NJ. The predictive value of biochemical markers of bone turnover for bone mineral density in early postmenopausal women treated with hormone replacement or calcium supplementation. J Clin Endocrinol Metab. 1997; 82: 1904-10.

5. Lindsay R, Hart DM, Aitken JM, MacDonald EB, Anderson JB, Clarke AC. Long-term revention of postmenopausal osteoporosis by oestrogen. Evidence for an increased bone mass after delayed onset of oestrogen treatment. Lancet. 1976; 1: 1038-41.

6. Horsman A, Gallagher JC, Simpson M, Nordin BE. Prospective trial of oestrogen and calcium in postmenopausal women. Br Med J. 1977; 2: 789-92.

7. Recker RR, Saville PD, Heaney RP. Effect of estrogens and calcium carbonate on bone loss in postmenopausal women. Ann Intern Med. 1977; 87: 649-55.

8. Kiel DP, Felson DT, Hannan MT, Anderson JJ, Wilson PW. Caffeine and the risk of hip fracture: the Framingham Study. Am J Epidemiol. 1990; 132: 675-84.

9. Prior JC, Vigna YM, Wark JD, Eyre DR, Lentle BC, Li DK, et al. Premenopausal ovariectomy-related bone loss: a randomized, double-blind, one-year trial of conjugated estrogen or medroxyprogesterone acetate. J Bone Miner Res. 1997; 12: 1851-63.

10. Prestwood KM, Pilbeam CC, Burleson JA, Woodiel FN, Delmas PD, Deftos LJ, et al. The short-term effects of conjugated estrogen on bone turnover in older women. J Clin Endocrinol Metab. 1994; 79: 366-71.

11. Bailey DA, McCulloch RG. Bone tissue and physical activity. Canadian journal of sport sciences $=$ 
Journal canadien des sciences du sport. 1990; 15: 229-39.

12. Winters-Stone KM, Snow CM. Site-specific response of bone to exercise in premenopausal women. Bone. 2006; 39: 1203-9.

13. Wolff I, van Croonenborg JJ, Kemper HC, Kostense PJ, Twisk JW. The effect of exercise training programs on bone mass: a meta-analysis of published controlled trials in pre- and postmenopausal women. Osteoporos Int. 1999; 9: 1-12.

14. Wallace BA, Cumming RG. Systematic review of randomized trials of the effect of exercise on bone mass in pre- and postmenopausal women. Calcif Tissue Int. 2000; 67: 10-8.

15. Berard A, Bravo G, Gauthier P. Meta-analysis of the effectiveness of physical activity for the prevention of bone loss in postmenopausal women. Osteoporos Int. 1997; 7: 331-7.

16. Kohrt WM, Snead DB, Slatopolsky E, Birge SJ, Jr. Additive effects of weight-bearing exercise and estrogen on bone mineral density in older women. $\mathrm{J}$ Bone Miner Res. 1995; 10: 1303-11.

17. Notelovitz M, Martin D, Tesar R, Khan FY, Probart $\mathrm{C}$, Fields $\mathrm{C}$, et al. Estrogen therapy and variableresistance weight training increase bone mineral in surgically menopausal women. J Bone Miner Res. 1991; 6: 583-90.

18. Garnero P, Sornay-Rendu E, Duboeuf F, Delmas PD. Markers of bone turnover predict postmenopausal forearm bone loss over 4 years: the OFELY study. J Bone Miner Res. 1999; 14: 1614-21.

19. Chesnut $\mathrm{CH}$, 3rd, Bell NH, Clark GS, Drinkwater BL, English SC, Johnson CC, Jr., et al. Hormone replacement therapy in postmenopausal women: urinary N-telopeptide of type I collagen monitors therapeutic effect and predicts response of bone mineral density. Am J Med. 1997; 102: 29-37.

20. Garnero P, Dargent-Molina P, Hans D, Schott AM, Breart G, Meunier PJ, et al. Do markers of bone resorption add to bone mineral density and ultrasonographic heel measurement for the prediction of hip fracture in elderly women? The EPIDOS prospective study. Osteoporos Int. 1998; 8: 563-9.

21. Kerr D, Morton A, Dick I, Prince R. Exercise effects on bone mass in postmenopausal women are sitespecific and load-dependent. J Bone Miner Res. 1996; 11: 218-25.

22. O'Connor JA, Lanyon LE, MacFie H. The influence of strain rate on adaptive bone remodelling. J Biomech. 1982; 15: 767-81.

23. Raab-Cullen DM, Akhter MP, Kimmel DB, Recker RR. Bone response to alternate-day mechanical loading of the rat tibia. J Bone Miner Res. 1994; 9: 203-11.

24. Rubin CT, Lanyon LE. Regulation of bone formation by applied dynamic loads. J Bone Joint Surg Am. 1984; 66: 397-402.

25. Rubin CT, Lanyon LE. Regulation of bone mass by mechanical strain magnitude. Calcif Tissue Int. 1985; 37: 411-7.
26. Li R, Liang L, Dou Y, Huang Z, Mo H, Wang Y, et al. Mechanical strain regulates osteogenic and adipogenic differentiation of bone marrow mesenchymal stem cells. BioMed research international. 2015; 2015: 873251 .

27. Heikkinen J, Kurttila-Matero E, Kyllonen E, Vuori J, Takala T, Vaananen H. Moderate exercise does not enhance the positive effect of estrogen on bone mineral density in postmenopausal women. Calcif Tissue Int. 1991; 49: S83-4.

28. Hawkins SA, Schroeder ET, Dreyer HC, Underwood S, Wiswell RA. Five-year maintenance of bone mineral density in women master runners. Med Sci Sports Exerc. 2003; 35: 137-44.

Резиме

\section{ХОРМОНСКАТА ТЕРАПИЈА ЈА НАМАЛУВА КОСКЕНАТА РЕСОРПЦИЈА, НО НЕ И ФОРМИРАЊЕТО НА КОСКИТЕ КАЈ АТЛЕТИ ВО ПОСТМЕНОПАУЗА} Сузи Ј Хонисет ${ }^{1}$, Дејвид Палјаро ${ }^{1}$,
Кети Тангалакис ${ }^{1}$, Бронвин Кингвел ${ }^{2}$,
Петер Ебелинг ${ }^{3}$, Робин Крејвен $^{4}$,
Џулијана Антонопилаи ${ }^{4}$,
Васо Апостолопулос $^{1}$, Лили Стојановска

${ }^{1}$ Центар за хронични болести, Школа за здравство и биомедицина, Универзитет Викторија, Викторија, Австралија ${ }^{2}$ Истражувачки институт „Бејкер Харт“, Прахран, Викторија, Австралија

${ }^{3}$ Оддел за дијабетес, ендокринологија и медицина, Универзитет во Мелбурн, Кралска болница во Мелбурн, Парквил, Викторија, Австралија

${ }^{4}$ Клиника за здравје на жените и дојките, болница „Фримејсон“, Источен Мелбурн, Викторија, Австралија

Вовед: Независно, хормонската терапија и вежбањето имаат добро воспоставени заштитни ефекти врз коскените параметри. Сепак, комбинираните ефекти на хормонската терапија и вежбањето се помалку јасни. Затоа, ги испитувавме ефектите на хормонската терапија на маркери на коскениот метаболизам кај жени во постменопауза подложени на редовни високо интензивни вежби.

Мет̄оqu: Во рандомизирана, двојно слепа студија, атлетите во постменопауза кои се натпреваруваат на ниво на Мастер, 20 недели при- 
мале или хормонска терапија (50 $\mu \mathrm{g}$ трансдермален естрадиол, $5 \mathrm{mg}$ МПА, $\mathrm{n}=8$ ) или плацебо $(\mathrm{n}=7)$. Жените беа тестирани пред и по третманот за плазма концентрациите на естрадиол, FSH, LH и серумскиот маркер за формирање на коска - остеокалцин (ОC); и уринскиот маркер за коскена ресорпција - пиридинолин (PYD) и деоксипиридинолин (DPD).

Резулйайи: Како резултат на третманот со хормонската терапија имаше значително намалување на нивото на FSH (73,3 $\pm 13,7$ до 48,6 $\pm 10,5 \mathrm{mmol} / \mathrm{L}, p=0,01)$ и маркерите за коскена ресорпција (PYD, 81,9 \pm 7,7 до 57,8 $\pm 3,7 \mathrm{nmol} /$ mmol Cr, $p=0,001$, и DPD, $18.5 \pm 3,1$ до $11,8 \pm$ $2,1 \mathrm{nmol} / \mathrm{mmol} \mathrm{Cr}, p=0,01)$. Естрадиолот и маркерите за формирање на коските не беа значително променети како резултат на хормонската терапија. Немаше промени кај кои било варијабли со плацебо третманот.

Заклучок: Хормонската терапија ја намали коскена ресорпција, но не и формирањето на коските, кај атлетите во постменопауза. Овие поволни намалувања на коскениот метаболизам обезбедуваат ефективен третман во комбинациja со високиот интензитет на вежбање за натамошно намалување на последователниот ризик од остеопороза и поврзани фрактури.

Клучни зборови: вежба, менопауза, коскен метаболизам, хормонска заменска терапија, естрадиол 